\title{
Sustainable Complete Class System in Gowa Regency South Sulawesi
}

\author{
Bustan* \\ Faculty of Social Science \\ Universitas Negeri Makassar \\ Makassar, Indonesia \\ bustan@unm.ac.id
}

\author{
Supriadi Torro \\ Faculty of Social Science \\ Universitas Negeri Makassar \\ Makassar, Indonesia \\ supriaditorro@unm.ac.id
}

\author{
Meysi Aurelia \\ Faculty of Social Science \\ Universitas Negeri Makassar \\ Makassar, Indonesia \\ meysiaurelia5@gmail.co
}

\begin{abstract}
This research aims to evaluate the implementation of a sustainable complete classroom system in Gowa Regency by looking at its implementation and the impact given to the quality of education in Gowa Regency. The results showed that the complete class system is sustainable in its implementation using an automated promotion system that is a system that does not recognize the stay of the class for students who do not successfully complete competencies according to the allocation of available time. The continuous complete classroom system in its implementation is still not running optimally, there are still errors related to understanding this policy and making the quality of education decrease, in addition there are still some teachers who do not understand about its technical implementation in the field. Research methods include: (1) Heuristic, this research uses field research and library research. Field research was conducted in several highland schools in Gowa district, namely at SDN Pa'ladingang, SMPN 1 Bontolempangan and in SMAN 15 Gowa and gowa district lowlands namely in SND Bontokamase, SMPN 1 Bontomarannu and SMAN 9 Gowa and also conducted interviews with gowa district government. For research the source library is obtained from libraries, local government documents, research results and journals (2) Criticisms, (3) Interpretations and (4) Historiography.
\end{abstract}

\section{Keywords: Education, Gowa District}

\section{INTRODUCTION}

Basically education is a conscious and planned effort to create a learning atmosphere and learning process that is able to get students to be active in developing their potential, in order to have religious spiritual strength, self-control, intelligence, personality, noble morality, and skills necessary by himself and the community, Nation and Country (Hamid darmadi, 2009). Pendidikan intends to help students empower their potential or develop their humanitarian potential. Therefore, the goal of education itself is human so that it can be interpreted that education is a process to humanize humans (Amos Neolaka, 2017).

The education that has been the benchmark so far is national education based on Pancasila and the Constitution of the Republic of Indonesia in 1945 and rooted in religious values, Indonesian national culture and response to the demands of changing times. The 1945 Constitution mandates efforts to educate the lives of ba ngsa and for the government to work on and implement a national teaching system governed. In the Outline of The Direction of State (GBHN: 1998) mentioned that: National Education is developed in an integrated and compatible between the lines, types and levels of education with other development sectors and also between regions and communities as government partners have a wide opportunity (Efendi, 2017). Therefore, the Gowa District Government issued a policy in the field of education, namely a sustainable complete class system.

This policy began to be socialized in 2011 under the leadership of Ichsan Yasin Limpo who is the 9th Regent of Gowa Regency which began to be implemented in 2012 (Harakan, 2017) and in 2013 a continuous complete class system has been implemented throughout elementary, junior high, high school/ vocational school in Gowa regency. this sustainable complete class system is taken into consideration to advance the quality of education and fulfill the right of the community to obtain a quality education.

Broadly broadly the continuous complete class system is divided into two, namely a limited continuous complete class and an unlimited continuous complete class. 1). The continuous complete class system is limited, which is done where every competency standard that then has some basic competencies, when the educator has taught the basic competency 1 then evaluates with the condition of completion that is the minimum completion criteria that have been determined by the school in the 2013 curriculum will obtain complete students and groups of students who are not completed 2). Continuous complete class system Is Not Limited, the meaning is after the learner learns a competency then is evaluated. When the students have evaluated then there are two complete groups 
and an incomplete group, then the group that has been successfully completed can immediately proceed to master Basic Competency II without having to wait for the group not to be completed, while the group that has not been completed is given repetition (remedial) then carried out evaluation until getting completed, then can only proceed to the next competency.

Components of the continuous complete class system include: 1) Curriculum. Curriculum is a set of plans and arrangements regarding the content and materials of the lesson and the way used as a guideline for teaching and learning activities. Repeated changes in the curriculum indicate an interaction between the curriculum and the real world. The wisdom that we can learn from the frequent changes in the curriculum is continious learning and continious impronvement for the development and development of human education can be arena continious learning process and continious improvement then the curriculum that is considered less perfect at first, in the next can create proven works of teaching learning activities. The components of the curriculum related to the continuous complete class system include: a) Annual Program, b) Semester program. c) Mapping of Basic Competencies Standards, d) Analysis of Minimum Completed Criteria, e) Syllabus, f) Learning Implementation Plan, with the characteristic of follow-up programs where students who obtain Basic Competencies are greater than the Minimum Completed Criteria following individual learning or enrichment activities. g) Educator's daily agenda, and h) Students' Reflection Book. 2)Early detection. Where we do early detection of students by observing their behavior, knowledge, and skills. If there is a child who has an abnormality then the child is put in an early clinic where we as educators provide special treatment for students who have the disorder. 3)Semester credit unit, 4)Assessment. Assessment of study results is given at all times and regularly through daily replays, monthly replays, midterm replays and end-of-semester replays. 5) Remedial or Early Clinic (P. K. Gowa, 2013).

Relevant research from the research conducted, namely, research from Mety Silfitriana, with the title Policy Evaluation of sustainable complete class system in Gowa District which discusses how the implementation of the complete class system is sustainable and evaluates the efficiency of the continuous complete class system in three schools namely, SMPN 1 Pallangga, SMAN 1 Pallangga and SMAN 2 Sungguminasa. From the results of Mety Silfitriana's research concluded that the policy of sustainable complete class system in Gowa Regency is less efficiently implemented due to the decline in the quality of education since the implementation of the continuous complete class system. This is evidenced by the declining national exam results from year to year (Safitriana, 2016).
The second research that was used as a relevant study in this study is, research from Febryanto yugustiadi Putra, in his thesis entitled Analysis of The Implementation of The Policy of The Program of Continuous Complete Classroom System in SMAN Based on the Regional Regulation of Gowa District No. 10 of 2013 in Bajeng, Pattalassang and Bontomarannu districts which discussed the suitability of the implementation of SKTB with Gowa District Regulation Number 10 year 2013 by focusing on three schools in Gowa Regency. From the results of febryanto yugustiadi Putra research found the results of the analysis of the implementation of the policy of the continuous complete class system program in general are in the category of good. In Bajeng sub-district is in a good category, Pattallassang sub-district is in the category of less and in Bontomarannu sub-district is in the category of enough (Febryanto Yugustiadi Putra, 2018).

\section{RESEARCH METHODS}

In this case the research method used is the historical method. The stages are done, among them: 1) Heuristic, meaning to find and collect historical sources related to the topic of research to obtain accurate sources. It can also be interpreted as a gathering activity of traces of the past, namely historical relics or any source of information in the sense of historical studies. Data collection activities or heuristics in this research are based on two ways, namely field research and library research. 2) Criticism, after conducting data collection then the next step that is done is because of the source or data found either through field research and library research. The results of academic or critical historical studies require proven facts. Therefore, the data obtained through the heuristic stage should be criticized or filtered so that the facts are as good as possible, the criticism in the form of criticism about its authenticity (external criticism) as well as the credibility of its contents (internal criticism). 3) Interpreatsi, is the process of interpreting historical facts in interpretation there are two important points namely synthesis (uniting) and analysis (deciphering). Interpretation is the next stage after the author through source criticism. Where the sources obtained such as the results of interviews from several informants are put together then drawn a conclusion. 4) Historiography, is the final stage of the historical research method. Once the source is collected then in the critique (selection) into data and then interpreted into facts, the final step is to arrange everything into one whole writing. 


\section{DISCUSSION}

1. The Process of The Emergence of Sustainable Complete Class System in Gowa Regency

Improving the quality of education in today's era of globalization and modernity is an important issue, while the management of educational organizations is necessary to improve the quality of education in order to move in one direction. Good and quality education is the basis for further development and progress. Therefore, education managers must respond to various government policies and community desires in terms of quality improvement with creativity, high innovation and good management strategy in the context of the optimization system of all elements of school management both input and output processes). Thus, there will be better and more advanced education to compete at the regional, national and global level (Hamid, 2017).

The Nation of Indonesia as a nation that is still said to be a developing country is looking for forms of how and efforts to become negar advanced especially in the field of education and education system in Indonesia is referring to the National Education System which is an education system that will bring progress and development of the nation and answer the challenges of this ever-changing era as the vision and mission of the National Education System set out in Law NO. 20 of 2003 on SISDIKNAS is : The realization of the education system as a strong and authoritative social pranata to empower all Indonesian citizens to develop into qualified human beings so that they are able and proactive to answer the challenges of ever-changing times.

The mission carried out by SISDIKNAS is: "To seek the expansion and equalization of opportunities to obtain a quality education for all people." (UU No 20 Tahun 2003, 2003). To realize the vision and mission of the National Education System set out in Law NO. 20 of 2003 requires a long and continuous process. In this case, the government is seen as the most appropriate to assist in realizing the vision and mission so that in Gowa Regency issue policies in the field of education namely a sustainable complete class system.

The Continuous Complete Class System was issued because it saw some problems related to the current education system, such as in the implementation of National Exams and the system of classroom living. Judging from the aspect of learning objectives, that the implementation of the National Exam has had an impact on the shifting orientation of the child in learning. The purpose of learning protégés is no longer in the frame of honing potential and ability, but instead learning for the purpose of passing the National Exam. Meanwhile, judging by the aspect of educational parity that the quality conditions of schools are very diverse, it is highly unlikely that uniform evaluation is possible and even unfair if it should be measured using the same size (standard). More or more when UN is used as a graduation standard for students in schools, considering the disparity in the quality of education in Indonesia is still very high (Moh. Zaini, 2003).

National Exams are considered less rational when only making 3-4 subjects as a reference for student graduation while those studied there are 917 subjects. In this case, the continuous complete class system no longer makes national exams the determinant of student graduation. Furthermore, the class residence system is implemented throughout the school if students are deemed to have not been able to complete 3 subjects in two semesters. Not getting into class or staying in class is a bad experience, sometimes making the child embarrassed to repeat in the old class, studying with friends whose age is below it. This issue may cause the child to drop out of school (Yusmiati, 2016). The causes of the child's stay in the classroom include the child, peers, teachers and family. Teachers often encounter children who have difficulty in the field, such as difficulty in making contact between contact with peers, isolated even awkward in association and so on. Such circumstances will be fatal, namely the grades of learning outcomes achieved by the child to be low which in the end the child becomes not in the class because the average grade does not meet the minimum completion criteria specified by the school Here the complete class system is continuously present in the form of remedial learning or repetition, where remedial learning is the repetition of some competencies that have not been completed without having to repeat all existing competencies.

\section{Implementation of Sustainable Complete Class System in Gowa Regency}

The complete class system is continuous in its implementation using the Automatic Promotion System which is a system that does not recognize the stay of the class for students who do not successfully complete the competency according to the allocation of available time. In the continuous complete classroom system there is also called remedial learning. Remedial learning in question is that some competencies that have not been completed can be repeated without having to repeat all competencies that have been completed. Remedial learning developed is an ongoing remedial learning that is intended to help students who have learning difficulties from the beginning. Each teacher is required to keep an eye on every student who has learning difficulties from the beginning, so as to determine the anticipation steps before the exam/replay is held.

The steps taken by teachers in providing continuous remedial in the continuous completion class system are: 1) Finding problems 2) Identifying 
problems 3) Problem analysis 4) Determining alternative actions 5) Devising remedial plan 6) Implementing remedial 7) Evaluating remedial results 8) Following up on remedial results.

After the above steps, there are students who do not achieve the competency stipulated. So educators can provide treatment in the form of:

1) Re-learning with different methods and media. Re-learning can be delivered by simplification of the material.

2) Providing guidance specifically, providing individual guidance to students who are experiencing difficulties.

3) The provision of tasks specifically, in order to apply the principle of repetition of special tasks needs to be multiplied so that students do not have difficulty in learning.

4) Utilization of peer tutors, peer tutors are classmates who have more proficiency that can be utilized in helping the theme that is still difficult.

The success of the continuous complete classroom system is actually determined by the role of the principal, especially a teacher, because they are the one who jumped directly into the implementation of this policy. The principal must also have a good relationship with the teacher and the student, and must also establish communication with the student's parents. Parents can be good partners for school success.

In addition, the role of the government is also very important in the implementation of the continuous complete class system, it has been stated in the Gowa District Regulation on sustainable due class system in article 18 points (1) and (2) which becomes the rights and obligations of local governments are: 1)The local government has the right to direct, guide, assist, and supervise the implementation of the Sustainable Complete Class System, 2) the local government in accordance with its authority is entitled and obligated to regulate , plan, implement, and evaluate each educational organization.

The role of the government in the implementation of the continuous complete class system as a policy maker, is to supervise and evaluate the implementation of the continuous complete class system Form the role of the government namely by socializing this continuous complete class system ranging from the district level, the District Technical Implementation Unit to the school. In addition, the strategy implemented in the continuous complete class system is in the form of workshops, training, socialization, mentoring through the development team of sustainable complete class system.

The data on the implementation of the workshop of the continuous complete class system in Gowa district was officially opened by the Regent of Gowa at that time. The workshop was held on
May 11-13, 2015, with materials strengthening the assessment of the continuous complete class system at the elementary, junior high, and high school/ vocational schools. The purpose of this activity is to strengthen the ability of teachers in making transfers of konowladge to students. The authors conclude, the form of the role of government in the complete class system is sustainable by socializing from the district level, after which sub-districts, and schools. The form of socialization by holding workshops, but not all teachers participate in the activity but there are representatives.

There are various factors that affect the implementation, both supporting and inhibiting factors. As for the factors that support the implementation of the continuous complete classroom system, namely: 1) SKTB has become a regional program with the local regulation No. 10 of 2013, 2) The response of education stakholders such as schools responds well, 3) Getting support from the community / parents of students.

Sedangkan faktor penghambat pelaksanaan sistem kelas tuntas berkelanjutan, yaitu : 1) Pemahaman sebagian masyarakat yang masih bervariasi terhadap kebijakan sistem kelas tuntas berkelanjutan. Masih adanya beberapa masyarakat yang tidak setuju terhadap kebijakan ini, mengganggap kebijakan ini sangatlah menguntungkan bagi siswa yang malas, 2) Masih Kurangnya kesadaran orangtua siswa. Hal ini menghambat implementasi SKTB dalam pencapaian tujuannya. Peran orangtua sangat dibutuhkan dalam pelaksanaan kebijakan ini terlebih lagi dalam mendukung dan membimbing anaknya agar dapat lebih baik atau mengalami peningkatan belajar., 3) Masih kurangnya respon dan pemahaman tentang sistem kelas tuntas berkelanjutan baik dari guru itu sendiri dan masyarakat. 4) Kesadaran siswa yang masih kurang. Ini merupakan salah satu faktor penghambat pelaksanaan SKTB. Dimana masih terdapat beberapa siswa yang memiliki pemikiran bahwa dengan adanya program ini akan menguntungkan mereka walaupun mereka tidak belajar dengan baik, mereka akan tetap naik kelas, meskipun mereka tidak datang ke sekolah pasti akan tetap naik kelas, 5) Masih kurangnya sarana pendidikan. Sarana pendidikan adalah salah satu sumber daya yang menjadi tolak ukur mutu sekolah dan perlu peningkatan terus menerus seiring dengan perkembangan ilmu pengetahuan dan teknologi. Dalam pelaksanaan SKTB masih terdapat sekolah yang masih memiliki sarana dan prasarana yang masih minim sehingga sulit untuk menggunakan metode pembelajaran yang bervariasi untuk memancing minat belajar siswa. 


\section{Impact of Continuous Complete Class} System on Education in Gowa District

Education evaluation is the activity of controlling, guaranteeing, and determining the quality of education on various components of education in every line, level, and type of education as a form of accountability for the implementation of education. The policy evaluation places the policy in the assessment of its implementation and consequently, as well as the continuous complete class system after seeing its implementation afterwards will be seen how the impact after the implementation of this continuous complete class system policy in Gowa Regency on the quality of education.

One of the most influential positive impacts so far of the ongoing complete classroom system is that students can complete their studies in a timely manner because there is no longer any reason to stay in class and pass the national exam. If there used to be a lot of students who stayed in the classroom maybe because of the fact that the lessons were not completed and the attendance was not enough $80 \%$. But in the classroom system, every basic competency in the learning implementation plan must be completed by enrichment from the teacher. If any student has not reached the Minimum Completed Criteria then remedial is carried out.

\section{CONCLUSION}

The continuous complete classroom system is a policy in the field of education from the Gowa District government that came into effect in 2012 by making 50 schools as referrals and in 2013 a sustainable complete class system has been implemented in Gowa Regency starting from elementary, junior high, high school, and MA. Sustainable complete class system aims to dismantle regulations in education that are considered less efficient.

Continuous Complete Class System in its implementation using The Outomatic Promotion System which is a system that does not recognize the stay of the class for students who do not successfully complete competencies according to the allocation of available time. The system is aware of components such as curriculum and early detection. The implementation of the current continuous complete classroom system has not been optimally implemented still influenced by various factors, especially the lack of understanding of this policy, which is due to the lack of socialization from the government to the community and students directly.

The continuous complete class system has an impact in the world of education in Gowa Regency. The impact of the continuous complete class system is: 1) Increasing student graduation rates, 2) The number of students who are increasingly lazy following the learning process due to the mis presumption of a continuous complete class system that then impacts on the declining quality of education in Gowa Regency.

\section{REFERENCES}

Amos Neolaka, G. A. A. N. (2017). Landasan Pendidikan. Kencana.

Efendi, Y. K. (2017). Pelaksanaan Program Pendidikan Pelatihan Di Dinas Tenaga Kerja Transmigrasi Dan Kependudukan Pemerintah Propinsi Jawa Timur. Khazanah Pendidikan: Jurnal Ilmiah Kependidikan, 10(2).

Febryanto Yugustiadi Putra. (2018). Analisis Keterlaksanaan Program SKTB di SMAN Berdasarkan Perda No.10 Tahun 2013 pada Kecamatan Bajeng, Pattallassang dan Bontomarannu. Universitas Islam Negeri Alaudddin Makassar.

Gowa, P. K. (2013). PERDA-NOMOR-10-TAHUN2013-TTG-SISTEM-KELAS-TUNTASBERKELANJUTAN.pdf.

Gowa, R. K. (2019). Dokumen program investasi infrastruktur jangka menenagah Kabupaten Gowa tahun 2015-2019.

Hamid darmadi. (2009). Konsep dasar pendidikan moral (1st ed.). Alfabeta.

Hamid, M. H. (2017). Penerapan Sistem Kelas Tuntas Berkelanjutan (Sktb) Di Sd Negeri Paccinongan Unggulan Kec. Somba Opu Kab. Gowa. http://repositori.uinalauddin.ac.id/12305/1/Penerapan Sistem Kelas Tuntas Berkelanjutan \%28SKTB\%29 di SD Negeri Paccinongan Unggulan Kec. Somba Opu Kab. Gowa.pdf

Harakan, A. (2017). Efektivitas pelaksanaan kebijakan sistem kelas tuntas berkelanjutan di Kabupaten Gowa. Journal of Chemical Information and Modeling, 53(9), 287. https://doi.org/10.1017/CBO9781107415324. 004

Ira, M. (2015). Sistem Pendidikan di Indonesia: antara keinginan dan realita. Jurnal Auladuna, 2(2), 233-245.

Moh. Zaini. (2003). KEBIJAKAN UJIAN NASIONAL Kajian Kritis Politik Pendidikan. 95-126. www.suparlan.com

Safitriana, M. (2016). Evaluasi kebijakan sistem kelas tuntas berkelanjutan (sktb) di kabupaten gowa. Universitas Hasanuddin.

UU No 20 Tahun 2003. (2003). 1, 6-8. https://doi.org/10.16309/j.cnki.issn.10071776.2003.03.004

Yusmiati. (2016). studi kasus kesulitan belajar siswa yang tinggal kelas. 41. 